\title{
Earthworm as eco treatment tool for removing organic matter pollutant: A synergy between L. rubellus vermiculture farmer and traditional tofu maker in the effort for making zero waste in tofu production
}

\author{
Anna E Persulessy ${ }^{1}$, Ajeng Arum Sari ${ }^{1}$, Yohanes Susanto ${ }^{1}$, Etih Hartati ${ }^{2}$, Rafindra Dwi Putra ${ }^{2}$, \\ ${ }^{1}$ Loka Teknologi Bersih, Lembaga Ilmu Pengetahuan Indonesia, Jl. Sangkuriang Komp.LIPI, GD.50, Bandung 40351, Indonesia \\ ${ }^{2}$ Departemen Teknik Lingkungan, Fakultas Teknik sipil dan Perencanaan, Institut Teknologi Nasional Bandung, Jl. PHH Mustafa No. \\ 23, Bandung 40124, Indonesia \\ *E-mail:ziemag@yahoo.com;anna001@lipi.go.id \\ DOI: $10.31364 /$ SCIRJ/v9.i10.2021.P1021893 \\ http://dx.doi.org/10.31364/SCIRJ/v9.i10.2021.P1021893
}

\begin{abstract}
Earthworms has been chosen as eco tool treatment since their ability to remove organic matter in waste has been reported everywhere. Due to high content of organic matter in tofu liquid waste and relative safe from pesticides and heavy metals contaminant and because of tofu makers release in water bodies without treating, therefore we are interested to study this liquid waste as an alternative food for feeding earthworm. Lumbricus rubellus is rich available in Indonesia and only view studies use this species for dealing with wastewater treatment. L rubellus culture is potential for feeding animal and curing some diseases of human. Every week tofu liquid waste was taken for testing its $\mathrm{pH}$, turbidity, $\mathrm{CODcr}$ and $\mathrm{BOD}_{5}$. After third week of studying there was increasing the population and bodies weight of $32 \%$ and $7.5 \%$ respectively. High efficiency removal of turbidity, CODcr and $\mathrm{BOD}_{5}$ were obtained in reactor that inhabited by $L$ rubellus rather than without having $L$ rubellus. Study shown that $L$ rubellus grows faster in tofu liquid waste rather than another slurry by breaking down high concentration of organic matter in its digestive pathway use their enzymes. $L$ rubellus produces a large number of cocoons, juveniles and granules cast appeared on the top layer of bed reactor which contains a number of organic matter eater-organism and attached as well as growth on the surface of aggregate gravels. There is possibility created between $L$ rubellus culture farmer and tofu makers for taking mutual benefit in term of economic point of view.
\end{abstract}

Key words: L. rubellus, tofu liquid waste, eco-treatment tool, organic matter, microorganism.

\section{Introduction}

Tofu is made by coagulating soy milk to create curds. The curds are then pressed and compacted into the gelatinous white blocks recognized as tofu. It is naturally gluten-free and low in calories. It contains no cholesterol and is an excellent source of iron and calcium.

www.sciri.org

(C) 2021, Scientific Research Journal

http://dx.doi.org/10.31364/SCIRJ/v9.i10.2021.P1021983

This publication is licensed under Creative Commons Attribution CC BY. 
It also contains isoflavones such as phytoestrogens, isoflavones may have both estrogen-agonist or estrogen-antagonist properties which is good for protecting some diseases. It is an important source of protein especially for vegans and vegetarians (Zhang et al. 2018; Megan Ware, RDN 2017; Alamu et al. 2017). Nonetheless if over-consumption of soybean products may also present some risks such as hormonal disturbances, carcinogenic and organotoxic of soy protein based on the clinical and experimental studies (Sukalingam K, Ganesan K, Das S 2015) and created worse memory of elderly in China and Indonesia had been reported (Hogervorst et al. 2008; Xu et al. 2015). Tofu used in numerous culinary dishes as protein bioavailability has been increasingly and easily obtain in almost all of traditional and modern market. However, the consequence of the tofu production causing a greenhouse gas emission (carbon foot print), grey water footprint which has been calculated throughout of cultivation, harvesting and production theoretically. For $1 \mathrm{~kg}$ of packed tofu, $16 \% \mathrm{CO}_{2} \mathrm{e}$ resulted from soybean production, $52 \%$ from tofu manufacturing, $23 \%$ from packaging and $9 \%$ from transportation referred to carbon footprint(Mejia et al. 2018) and for $1 \mathrm{~kg}$ of soybean curd product (Tofu) in Bandung-Indonesia requires $2.154 \mathrm{M}^{3}$ of fresh water referred to water footprint(Haidir and Sudrajat 2014). Tofu makers in Indonesia still use traditional production for maintaining the texture and sensory quality of tofu from one generation to another generation. However, this process is considered to be inefficient not in term of large fresh water uses only but also the negative impact of environment since tofu makers have discharged large amount of liquid waste into sewer system. Studies shown that concentration level of BOD 5 and CODcr was varies in the range of $5.981-6.525 \mathrm{mg} / \mathrm{L}$ for CODcr and $2.900 \mathrm{mg} / \mathrm{L}$ for BOD $($ Oktariany and Kartohardjono 2018) and also 6.000 - 8.000 mg/L for BOD5 and $7.500-14.000 \mathrm{mg} / \mathrm{L}$ for CODcr has been reported(Faisal et al. 2015). Due to high concentration of organic matter in tofu liquid waste, researchers put a hope for studying about biogas, however tofu liquid waste could not be used directly as biogas substrate due to high nitrogen content which was not suitable to methanogen microorganism on biogas digester(Rahmat, Hartoyo, and Sunarya 2014). For controlling ratio carbon-nitrogen in tofu liquid waste is not easy for operator and also the investment for biogas process is considered not feasible for traditional tofu makers presently. Therefore, to reduce high level of $\mathrm{BOD}_{5}$ and CODcr in tofu liquid waste, we use ecotreatment tool for removing organic matter in laboratory scale. In this study earthworm was chosen since their ability for removing organic matter has been reported everywhere(Nie et al. 2015; Kumar and Ghosh 2019; Sinha, Bharambe, and Chaudhari 2008) and tofu liquid waste used as alternative food for feeding earthworms instead of cow dung which usually used in vermiculture in Indonesia. By doing so, all process of tofu production will be relative zero waste (fig. 1) and the treated water can be reused for the process of production. Earthworm species Lumbricus rubellus has chosen due to rich available in Indonesia and only view of study use this species for dealing with wastewater treatment. The growth of organic matter eater-microorganisms on aggregate gravels in column reactor and removal efficiency of organic matter pollutant are studied as well. We would like to understand a suitable environmental condition relates to the healthy growth of L rubellus if use tofu liquid waste as food due to there is demand of healthy and uncontaminated earthworms which is used as protein sources and additive feed for aquaculture and poultry (Byambas et al. 2019; Edy Parwanto et al.

www.scirj.org

(C) 2021, Scientific Research Journal

http://dx.doi.org/10.31364/SCIRJ/v9.i10.2021.P1021983

This publication is licensed under Creative Commons Attribution CC BY. 
2016; Julendra, Zuprizal, and Supadmo 2010; Damayanti et al. 2008). It is also used as raw material of some kind of medicine(Septianda,

Debora, and Rochmanti 2012; Reynolds, Wilma, and Reynolds 2017; Cooper, Hirabayashi, and Balamurugan 2012; Shen 2010; Mihara et al. 1991).

\section{Materials and Methods}

\section{Materials}

\section{Tofu liquid waste}

Tofu's liquid waste was collected from central of Tofu makers Cibuntu at Bandung City, West Java. Indonesia. Traditional tofu makers use the procedure for production of tofu as shown in figure 1.

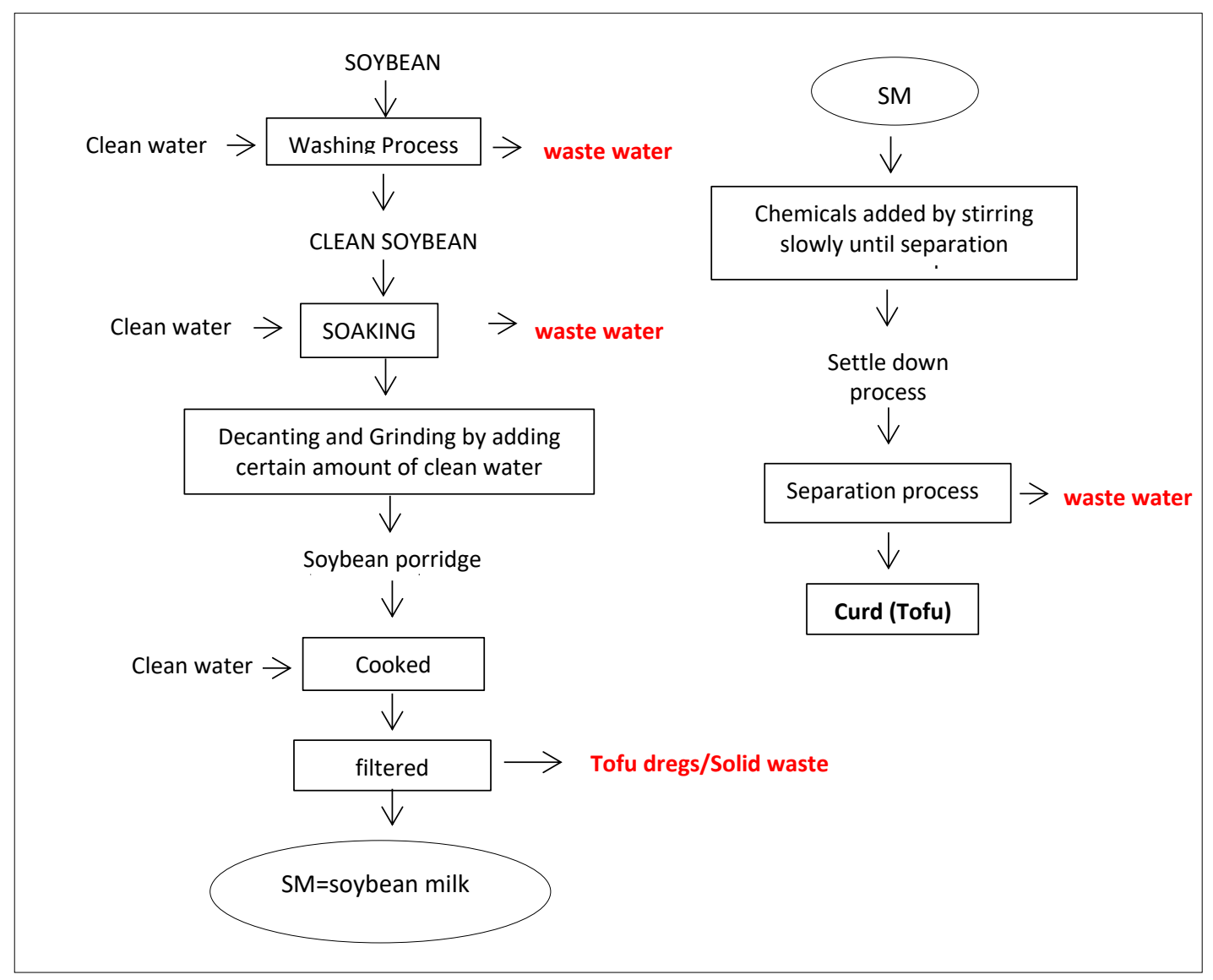

Figure.1. Flow chart of Tofu making

20 liters of tofu liquid waste randomly and well mixed was taken and put into the plastic drum and bring to Laboratory and then transferred to 7 litter of plastic bucket (Fig.3) which was equipped small capacity aerator to blow air into this tofu's liquid waste in order to avoid foul odor. Study was conducted at ambient temperature around $25-27^{0} \mathrm{C}$. Sampling was done twice a week for observing the fluctuation of effluent waste during three months and the characteristic of tofu liquid waste (table 1) does not change as has been 
done before in previous study(Persulessy A E, Rosmalina RT, Hartati E 2020). Triplicates batch experiment has been performed and the data was calculated as average and shown in this research.

Tabel 1. Characteristic of Tofu liquid waste

\begin{tabular}{llll}
\hline C & Parameter & unit & Concentration range \\
\hline 1 & $\mathrm{pH}$ & - & $4-5$ \\
2 & Turbidity & $\mathrm{NTU}$ & $1.206-1.600$ \\
3 & CODcr & $\mathrm{Mg} / \mathrm{L}$ & $5.000-8.000$ \\
4 & BOD5 & $\mathrm{mg} / \mathrm{L}$ & $5.400-7.700$ \\
\hline
\end{tabular}

\section{Earthworms species lumbricus rubellus}

Earthworms were collected from the local vermiculture farmer. A little amount of origin cow dung-soil mixture together with earthworms were transferred to laboratory as shown in fig 2 . This study used 40 adult earthworms (approx. 20 grams) with length average $10 \mathrm{~cm}$ in $0.002 \mathrm{~m}^{3}$ of cow dung-soil mixture bed exist in the reactor A. Cow dung-soil mixture with the same amount was transferred into reactor B without having earthworms. These earthworms were provided 5 days for acclimatization at new environment while trickling of tofu's liquid waste passed through entire of media layer slowly for acclimatization before the effluent was collected for analyzing.

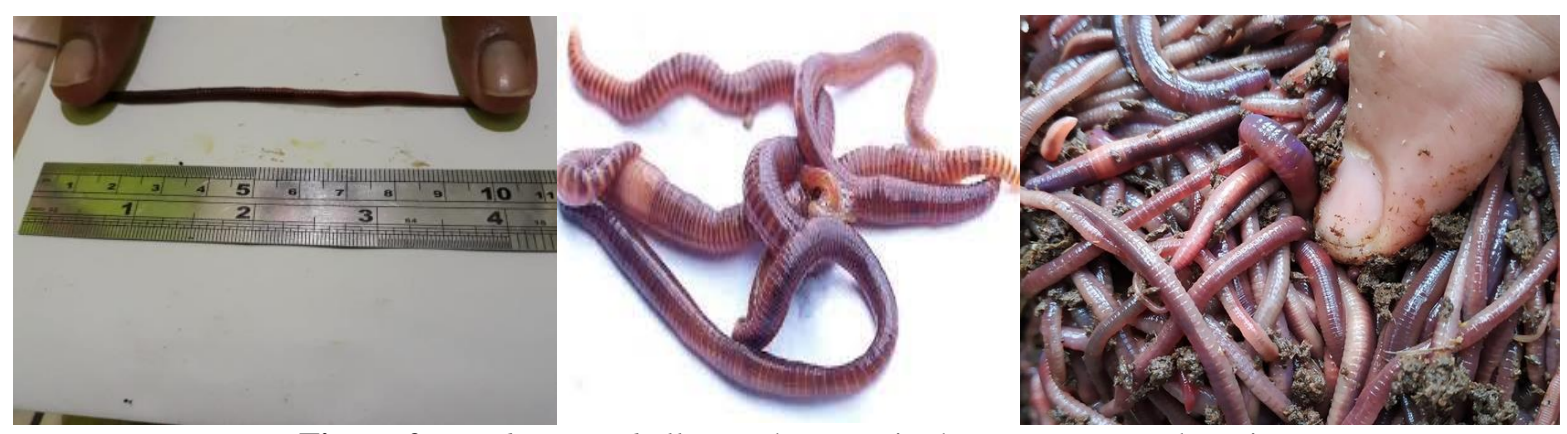

Figure 2. Lumbricus rubellus earthworms in the West Java, Indonesia

\section{Setting up a column reactor}

Two identical column-type reactors were made of transparent acrylic and equipped with four drain valves (sampling ports) of each reactor, with rectangular shape of $10 \times 10 \times 100 \mathrm{~cm}$ were used. To protect worms from predators and to avoid a direct contact with sunlight, reactors were monitored every day. Material support in this column reactors consists of four layers with different size of aggregate gravels as shown in Fig.3. 

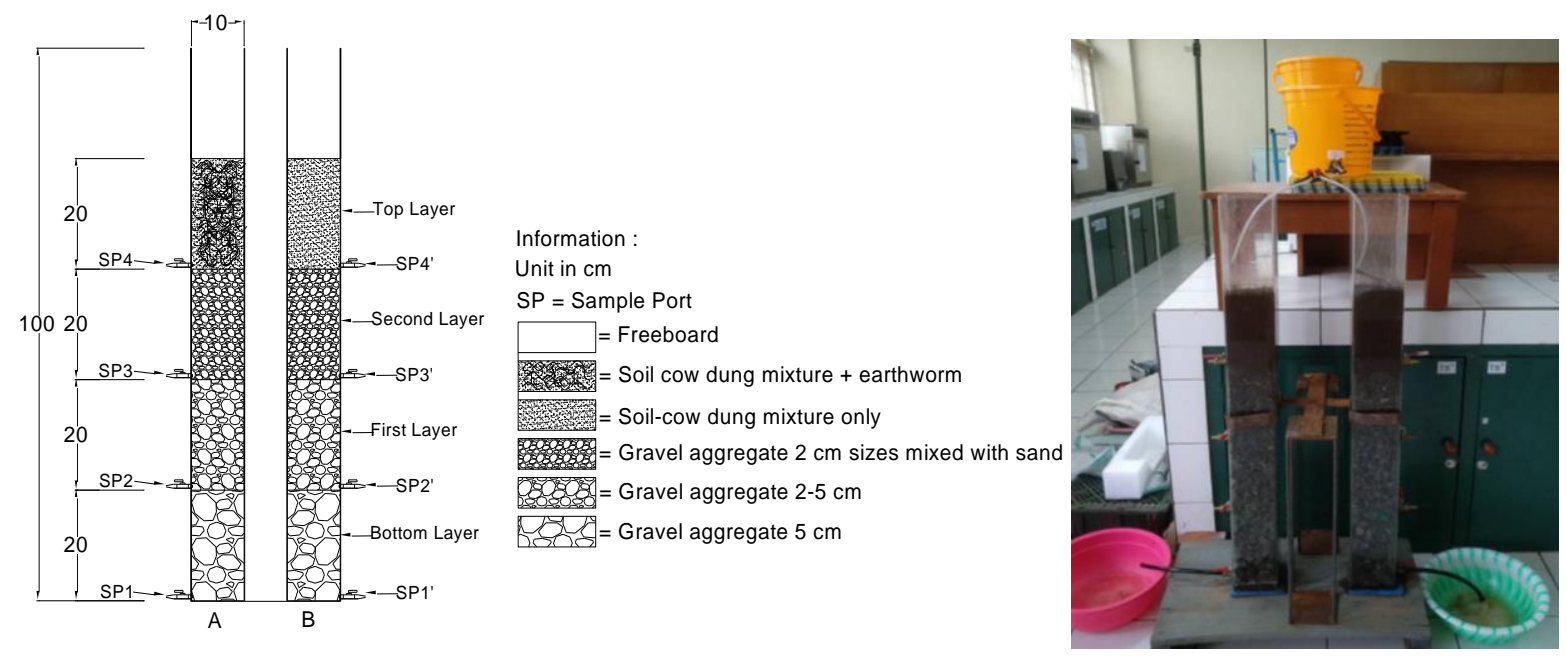

Fig 3. Two identical column-type reactors

Two sprinkler system used for trickling tofu liquid waste that allowed uniform distribution on bed material (top layer) of both reactors A and B as control. Tofu liquid waste from the drums above these reactors flowed through flexible plastic hose by gravity. Tofu liquid waste percolated down through aggregate gravels of two reactors A and B. All valves of sampling ports were closed when tofu liquid waste flows into both of reactor until this liquid waste goes up to second layer or below of top layer. Furthermore, the valve of bottom layer (sampling ports P1and P1') plays as the effluent control to keep the flow rate of influent and effluent on these two reactors without letting the beds become flood with tofu liquid waste. Of P1, P1' and P4, P4' treated tofu liquid waste was collected and analyzed for BOD, COD, $\mathrm{pH}$, turbidity, and visual observation on support materials (aggregate gravels) relates to growth of organic matter eatermicroorganism was performed.

\section{HRT and HLR}

HRT (hydraulic retention time) is an actual time has been spent by earthworms with tofu liquid waste to retrieve organic matter (turbidity, $\mathrm{CODcr}$ and $\mathrm{BOD}_{5}$ ) from it as food. In this study tofu liquid waste was flowed into reactor $\mathrm{A}$ and $\mathrm{B}$ was $4 \mathrm{ml} / \mathrm{minute}$ of each with porosity of entire media was $18 \%$ and HRT for each reactor was 1 hour and 30 minutes and kept constant during study was taking place. Hydraulic loading rate (HLR) depends upon the number of live adult earthworms functioning per unit area in bed reactor. In this study, HLR was $0.024 \mathrm{~m}^{3} / \mathrm{m}^{2}$.hour as have done in previous study(Persulessy A E, Rosmalina RT, Hartati E 2020).

\section{Methods}

Tofu liquid waste which has been treated through column reactor was analyzed for $\mathrm{pH}$, turbidity, chemical oxygen demand and biological oxygen demand by following the Indonesia Standard which were SNI 06-6989.11-2004 for pH, SNI 06-6989.25-2005 for

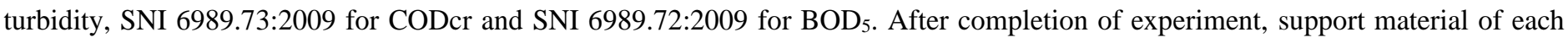
layer was taken to be analyzed under the microscope for microorganism growth observation.

$$
\text { www.sciri.org }
$$

(C) 2021, Scientific Research Journal 


\section{Results and discussion}

\section{In situ observation}

Daily observation has been done for reactors (A and B). Symptoms like foul odor, percolation of tofu liquid waste through the bed reactors (top layers), appearance of top layer, second layer, first layer and bottom layer were observed. Direct sunlight exposure to earthworm was not good and also if no sunlight at all caused earthworm dead within 7-10 days. Moderate sunlight emission will be good for this earthworm to maintain healthy life. No choked occurred and smooth percolation of liquid waste. After 5 days acclimation no cocoons appeared however at one week after acclimation and the beginning of second week, copulation of earthworm occurred by ejecting many of "cocoon" attached on the wall of reactor A and the color was whiteness. This was indicated that earthworm fertilize the eggs. At third week there was a bit fault odor detected in SP2, SP2' and SP3, SP3' (sampling ports) when we did release of this liquid waste of both reactors. The possibility came from very less dissolved oxygen in these layers or the anoxic condition had been taking place. At reactor A where earthworms were living, seems the agility and movement of earthworm quite good and after completion this experiment at third week, we found the number of earthworms become average 53 worms of three batch experiment so there were another 13 young worms with the length average $6 \mathrm{~cm}$ or showed 32\% population increased and some juveniles appeared in top layer of reactor. We did not calculate a number of juveniles due to they did not show their significant role for removing organic matter. After separating these 13 young worms, we weigh of 40 adult worms to found out total body weight and surprisingly there was increase of body weigh from 20 grams becomes 23 grams or average $7.5 \%$ of each body weigh increased after 3 weeks staying in reactor A. Meanwhile feeding worms with swine manure shown there was 30\% population increased during 4 weeks experiment by using Eisenia Andrei species as has been reported(Li et al. 2008). This was indicated that tofu liquid waste is good food for feeding earthworm because of high organic matter and some minerals in it and no interfere heavy metals during production of Tofu. Temperature, lighting and moisture also quite support for this study. No lighting exists during this experiment and only lighting and fresh air comes from windows in laboratory in day time.

www.scirj.org

(C) 2021, Scientific Research Journal

http://dx.doi.org/10.31364/SCIRJ/v9.i10.2021.P1021983

This publication is licensed under Creative Commons Attribution CC BY. 


\section{Microscopic Observation}

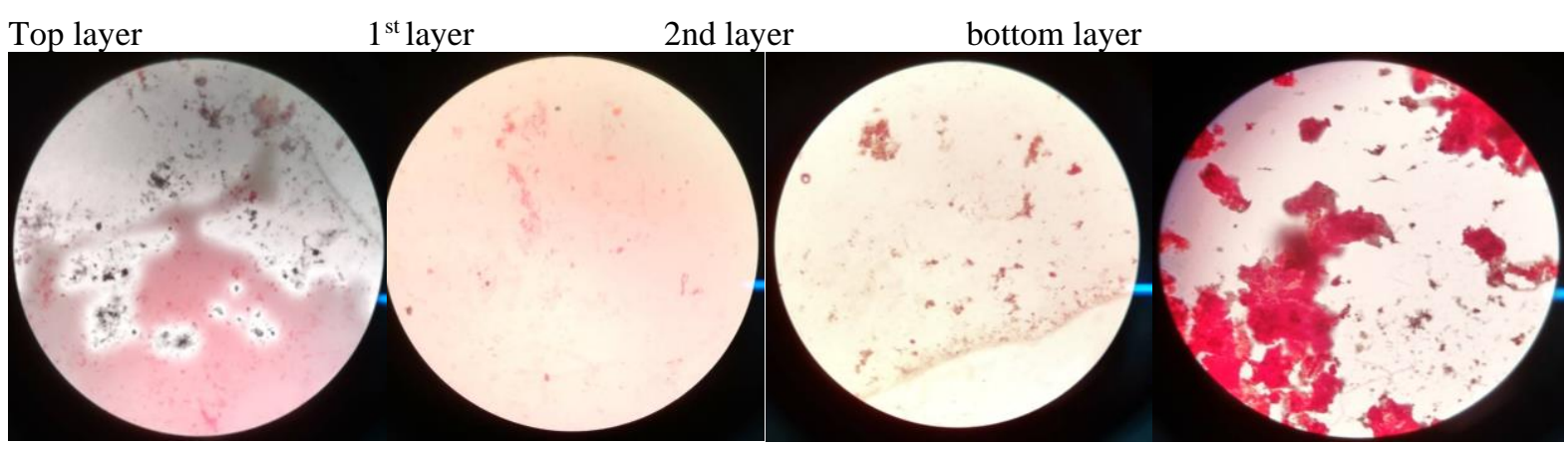

Fig. 4. Microscope photograph of each layer on reactor A

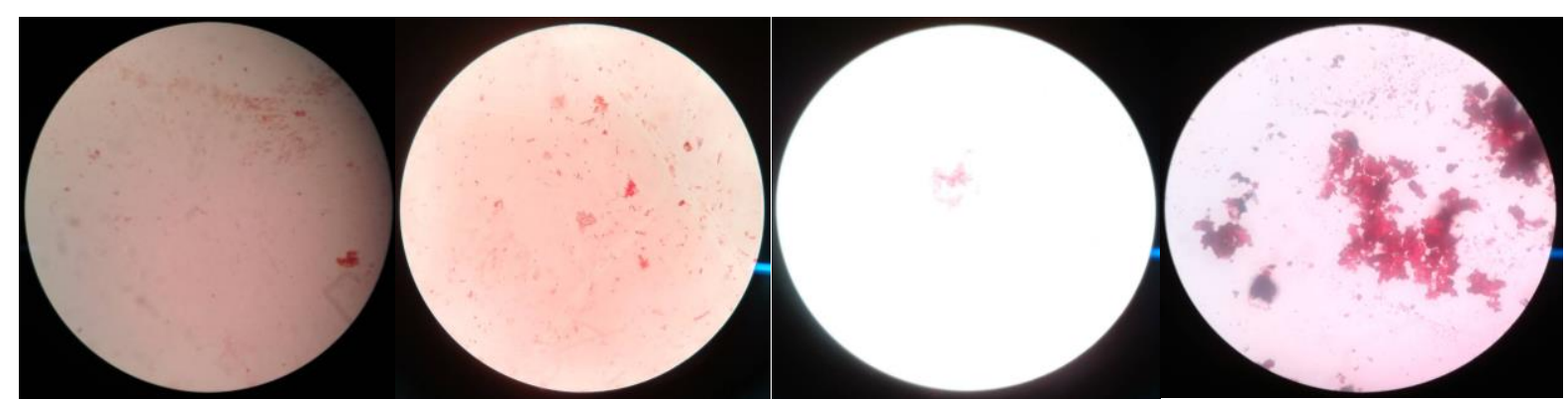

Fig. 5. Microscope photograph of each layer on reactor B

After treating tofu liquid waste completely, randomly aggregate gravel of each layer were taken for microscope observation with magnification 1000x. Results showed that all support materials were covered by basil and coccus microorganisms types in filament that consisted of staphylo, strepto, diplo and mono configurations on reactor A and B. Growth of microorganisms occurred more density on reactor A rather than reactor B. It showed that earthworms were release some microorganisms aerobic and anaerobic from casts that formed a colony of microorganisms on the surface of each aggregate gravels (Fig 4). According to Parle (1963) filamentous fungi and yeasts increased in number rapidly after the cast was produced(Parle 1963a). Microorganism in reactor B comes from tofu liquid waste as suspended phase which passed through aggregate gravels and also from cow dung-soil mixture taken from vermiculture farm as control (Fig 5). A number of studies were mainly focused in the earthworm guts and casts with relation to kind of diets and earthworm species(Parle 1963b; Gómez-Brandón et al. 2011; Gómez-Brandón, Lores, and Domínguez 2012; Aira et al. 2016; Knapp et al. 2009; Schönholzer, Hahn, and Zeyer 1999). Based on the DNA extracted was taken from substrates, the earthworms' gut contents and casts revealed that the gut and cast microbiota was strongly influenced by the food source ingested(Knapp et al. 2009). Another study reported that cocoons microbiome of the earthworms Eisinia Andrei and E. fetida were dominated by three vertically-transmitted symbionts, Microbacteriaceae, Verminephrobacter and ca. Nephrothrix and both ended showed high rate of sequence variation. This study was mentioned that during cocoons formation, cocoons are colonized with bacteria from its hosts and environment(Aira, Pérez-Losada, and Domínguez 2018). On the bottom layers (SP1 and SP1') of two reactors showed the excellent growth of microorganisms if compared to the top layers of two reactors (SP4 and SP4'). This was anaerobic microorganisms settled in the bottom of aggregate gravel and took

\section{www.scirj.org}

(C) 2021, Scientific Research Journal 
action for eating organic matter. On the top layers (SP4 and SP4') of two reactors were aerobic microorganism which was dominant and on first layer and second layer (SP2, SP2', SP3 and SP3') were possible anoxic condition. Study showed that aerobic and anaerobic bacteria also presence in earthworm gut and casts(Alauzet et al. 2001) whilst has been mentioned also that microbes growth under both aerobic and anaerobic conditions more abundant in the earthworm intestine than in the beech forest soil from which the worms were obtained(Karsten and Drake 1995). During progress through digestive system in earthworm intestine there is a dramatic increase in numbers of micro-organisms of up to 1000 times have been reported(Edwards and Fletcher 1988). It shown that earthworms acted as biomagnification microorganisms in its intestine and then release in the casts form contains microorganism for helping maintain the existence of microorganisms in reactor. The length of intestine approximately $90 \%$ of whole $L$ rubellus earthworm body that allows to absorb many organic and inorganic minerals in their diet and released through casts. Recent study regarding to $\mathrm{C}^{13}$ tracer showed that more than $85 \%$ mineral-associated organic matter (MOM) presence in casts(Vidal et al. 2019). The main diet for earthworm was organic and only a view microorganism like protozoans, Actinomycete, bacteria and fungi have been found to be part of earthworm diet(Byzov et al. 2007). Microbial presence in intestine are bacterial, fungal and actinomycetic populations were obtained in three species of earthworm; Lumbricus terrestress, Allolobophora caliginosa and A. Longa(Parle 1963b). Such genus Bacillus, Aeromonas, Pseudomonas, Flavobacterium, Nocardia, Gordonia, Vibrio, Clostridium, Proteus, Serratia, Mycobacterium, Klebsiella, Azotobacterial, and Entorobacter have been reported in the digestive tract of earthworm(Oligochaeta)(Hortensia and David 2009). Meanwhile in intestine of $L$ rubellus earthworm was found Bacillus megatarium(Fischer et al. 1997), Acidobacteria, Paenibacillus, Pseudomonas sp., as well as Actinobacteria have been reported (Singleton et al. 2003). This study clearly showed that there was difference between aggregate gravels at reactor A and B in term of the density of microorganisms during observation. Source of microorganisms from earthworms' casts, cow dung-soil mixture and from suspended tofu liquid waste. L rubellus has casts size bigger than Eisenia hortensis(Canti and Piearce 2003) that means more microorganisms released into reactor. These microorganisms were attached on the surface of aggregate gravel and develop biofilms; some are growth and some detached on the surface of aggregate gravel. Physical, biologic and chemical processes determine biofilm formation. Organic matter which was transported to surface by molecular diffusion and forming a conditioning layer which will influence subsequence adsorption and attraction of microorganism to the surface of aggregate gravel. This process can be monitored clearly by using digital time lapse microscopy imaging (DTLM)(LappinScott and Bass 2001).

\section{pH of treated tofu liquid waste}

According to Curry, earthworms are absent in very acid soils ( $\mathrm{pH}<3.5)$ and are sparse in soils with pH below 4.5(Räty and Huhta 2003). However, in this study earthworms still alive in the extreme $\mathrm{pH}$ when acclimatization for first time experiment took place where $\mathrm{pH}$ of tofu liquid waste range between 4-5(table 1) passed through reactor A until third week of study. It was indicated that L.rubbelus be able

www.sciri.org

(C) 2021, Scientific Research Journal

http://dx.doi.org/10.31364/SCIRJ/v9.i10.2021.P1021983

This publication is licensed under Creative Commons Attribution CC BY. 
to adapt in this condition in three consecutive study. Treated tofu liquid waste that passed through reactors was taken from bottom sampling port reactors and also from the top sampling port of A and B reactors every week after acclimatization for $\mathrm{pH}$ testing, turbidity, CODcr and BOD5.

Tabel 2. $\mathrm{pH}$ value of treated tofu liquid waste in both reactors

\begin{tabular}{|c|c|c|c|c|c|c|}
\hline \multirow{3}{*}{ Week } & \multirow{3}{*}{$\begin{array}{l}\text { pHvalue } \\
\text { treating }\end{array}$} & \multirow{3}{*}{ before } & \multicolumn{4}{|c|}{$\begin{array}{l}\text { pH value of treated tofu's liquid } \\
\text { waste }\end{array}$} \\
\hline & & & \multicolumn{2}{|c|}{ Reactor A } & \multicolumn{2}{|c|}{ Reactor B } \\
\hline & & & SP1 & SP4 & SP1' & SP4' \\
\hline 0 & 4,5 & & 7.6 & 6.7 & 7.2 & 5.8 \\
\hline $1 \mathrm{st}$ & 4,5 & & 7.1 & 5.6 & 5.7 & 6.6 \\
\hline 2nd & 4,7 & & 7.1 & 6.2 & 5.6 & 6.6 \\
\hline 3 th & 4,5 & & 7.4 & 5.3 & 7.3 & 5.0 \\
\hline
\end{tabular}

In general, $\mathrm{pH}$ value of treated tofu liquid waste has changed from acidic became neutral in sampling port P1(Tabel.2) and interestingly $\mathrm{pH}$ on the top of reactor A become neutral followed by each layer where inhabits of earthworms. L rubellus earthworm most perhaps of release some granules contains calcium carbonate are known to be produced by the calciferous glands of earthworms through its casts(García-Montero et al. 2013; Gago-Duport et al. 2008; Canti and Piearce 2003; Crang, Holsen, and Hitt 1968; Versteegh, Black, and Hodson 2014) and also from excreta likes mucus and urine that plays important role for increasing and stabilizing of pH environment to be neutral and slightly basic. In calcic mull condition the density of earthworm higher than acidic mull(Salmon 2001) and has been proven that in this study the population and weight increased by $32 \%$ and $7.5 \%$ respectively. A large source of calcium intake by earthworm might come from tofu liquid waste where in production process was added one of calcium chloride or calcium sulfate or calcium lactate as coagulant in certain amount for determining the product texture, flavor and yield (Leiva, Rodríguez, and Muñoz 2011; Jayasena, Tah, and Nasar-Abbas 2014; Prabhakaran, Perera, and Valiyaveettil 2006; Shih, Hou, and Chang 1997; Zhang et al. 2018). Furthermore, this coagulant was absorbed by glands and release it in granules form as casts. Casts contains mineral nitrogen levels were greater than those of soil; the major part of the inorganic nitrogen occurred as ammonia which was rapidly converted to nitrate(Parle 1963a). Several studies also described another role of earthworms which works for nitrogen fixation and phosphorous solubilizing of composting process (Hoang et al. 2016; Aira, Monroy, and Domínguez 2007). Study has mentioned also that earthworm casts have been proven experimentally to have a higher acid-base buffering capacity in comparison with that of the initial soil(Kul'bachko et al. 2015; Didur et al. 2019). pH environment in this reactor might was regulated by L rubellus, since many reports have proven that during vermifiltration process $\mathrm{pH}$ environment changed become neutral, even though in these reports do not show the calcium

www.scirj.org

(C) 2021, Scientific Research Journal

http://dx.doi.org/10.31364/SCIRJ/v9.i10.2021.P1021983

This publication is licensed under Creative Commons Attribution CC BY. 
compound content presence in their liquid waste. Other possibility since earthworm release urine which contains urea-ammonium compound which will increase $\mathrm{pH}$ value. This mechanism of $\mathrm{pH}$ changing still remain challenge for researchers. The role of buffer compound present in the reactor which has maintained to be stable in range 6-8 also another challenge to know its mechanism. Apparently at $\mathrm{pH}$ neutral as shown at SP1; earthworms can be a trigger for accelerating the microbe activities by enhancing the population of microorganisms which were spread out on the surface of aggregate gravels as shown in fig 4 . This pH was good condition for organic matter eater-microorganism and the possibility was the neutralophiles microorganisms in range pH 5.5-9(Krulwich, Sachs, and Padan 2011) which growth onto the surface of aggregate gravels. However, in fig 5 does not shows excellent growth of microorganisms since earthworms absent in these aggregate gravels and only comes from remaining cow dung soil mixture also got from tofu liquid waste in suspended form.

\section{Organic Matter removal}

In general, efficiency removal of turbidity was not showing the same pattern between reactor A and B however both reactors showed the efficiency removal was increase versus time. At third week the efficiency removal was $99.3 \%$ and $99.2 \%$ obtained on reactor A at sampling port (SP1) and sampling port (SP4) respectively. There was anomaly happened at (SP1') at reactor B which showed efficiency removal of turbidity was only $45.8 \%$ and in contrary showed at SP4' where efficiency removal of turbidity could be achieved $98 \%$. High efficiency removal of turbidity most possibly comes from earthworms which digested this suspended particle and released a large number of bacteria through casts. Earthworms also improve the total specific surface area of aggerate gravel, by enhancing the ability to adsorb organic and inorganic substances from wastewater(Sinha et al. 2010).These microorganisms spread out not only on the top layer but penetrated until the bottom of reactor A. Created microorganism colony on the surface of aggregate gravels and attached on it. When tofu liquid waste passed through this media, suspended particles was slightly endured due to some physical force between tofu liquid waste (liquid phase) and aggregate gravel (solid phase) and influenced by HRT. It will provide the opportunities for organic matter eater-microorganisms to take action by eating this suspended particle as organic matter. HRT also quite important to determine efficiency removal of organic matter. If HRT is increased, the efficiency removal become increase(Sinha, Bharambe, and Chaudhari 2008; Singh, Bhunia, and Dash 2019).

Tabel 3. Type of waste and its removal efficiency of organic matter with different of HRT

\begin{tabular}{|c|c|c|c|c|c|c|c|c|}
\hline $\begin{array}{l}\text { Earthworm } \\
\text { species }\end{array}$ & $\begin{array}{l}\text { Type of } \\
\text { waste }\end{array}$ & $\begin{array}{c}\text { HRT } \\
\text { (hours) }\end{array}$ & $\begin{array}{c}\text { Initial parameter } \\
\text { (mg/L) only } \mathrm{pH} \\
\text { unitless }\end{array}$ & $\mathrm{pH}$ & $\begin{array}{l}\text { Turbidity } \\
\text { removal } \\
(\%)\end{array}$ & $\begin{array}{l}\text { BOD5 } \\
\text { removal } \\
(\%)\end{array}$ & $\begin{array}{c}\text { CODcr } \\
\text { removal } \\
(\%)\end{array}$ & References \\
\hline $\begin{array}{l}\text { Earthworms } \\
\text { E. fetida, P. } \\
\text { excavatus, and }\end{array}$ & $\begin{array}{l}\text { Dairy } \\
\text { industry }\end{array}$ & 6-10 & $\begin{array}{l}\mathrm{pH}: 3.64-3.83 \\
\text { Turbidity:3.420- } \\
3.475 \\
\text { COD:>15.000 } \\
\text { BOD:103.000- } \\
136.000\end{array}$ & $\begin{array}{l}6.52- \\
7.45\end{array}$ & $\begin{array}{l}99.21- \\
99.3\end{array}$ & $\begin{array}{c}98.98- \\
99.49\end{array}$ & $80-90$ & $\begin{array}{l}\text { (Sinha and } \\
\text { Bharambe } \\
\text { 2006) }\end{array}$ \\
\hline
\end{tabular}




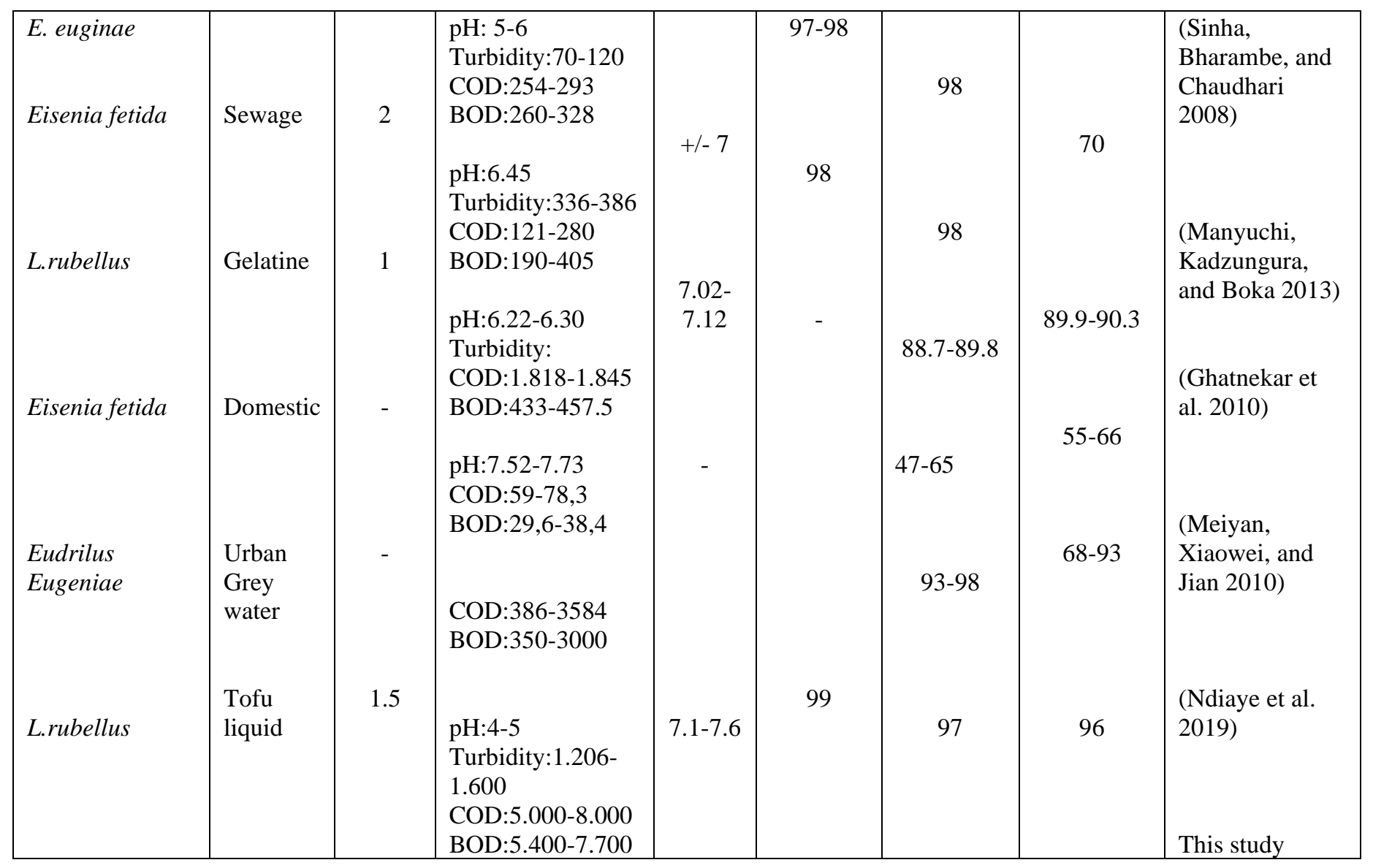

Table 3 shows the efficiency removal of organic matter related to several waste that has been treated by using some species of earthworms. At reactor B the efficiency removal of turbidity was inconsistency started from first week until third week of study. The effect of efficiency removal at reactor B, only come from cow dung-soil mixture microorganisms on top layer which was attached on the surface of aggregate gravels and some from microorganisms that inhabits tofu liquid waste which was suspended during passed through the reactor. The fluctuation of efficiency removal each week, might be possible due to complexity of interaction between microorganism and environment in reactors and relates to presence or absent of oxygen as described on microscope observation. Whereas CODcr and $\mathrm{BOD}_{5}$ showed a similar pattern of removal efficiency in reactor A (SP1 and SP4) and also at (SP1' and SP4') in reactor B (Graph 1). 


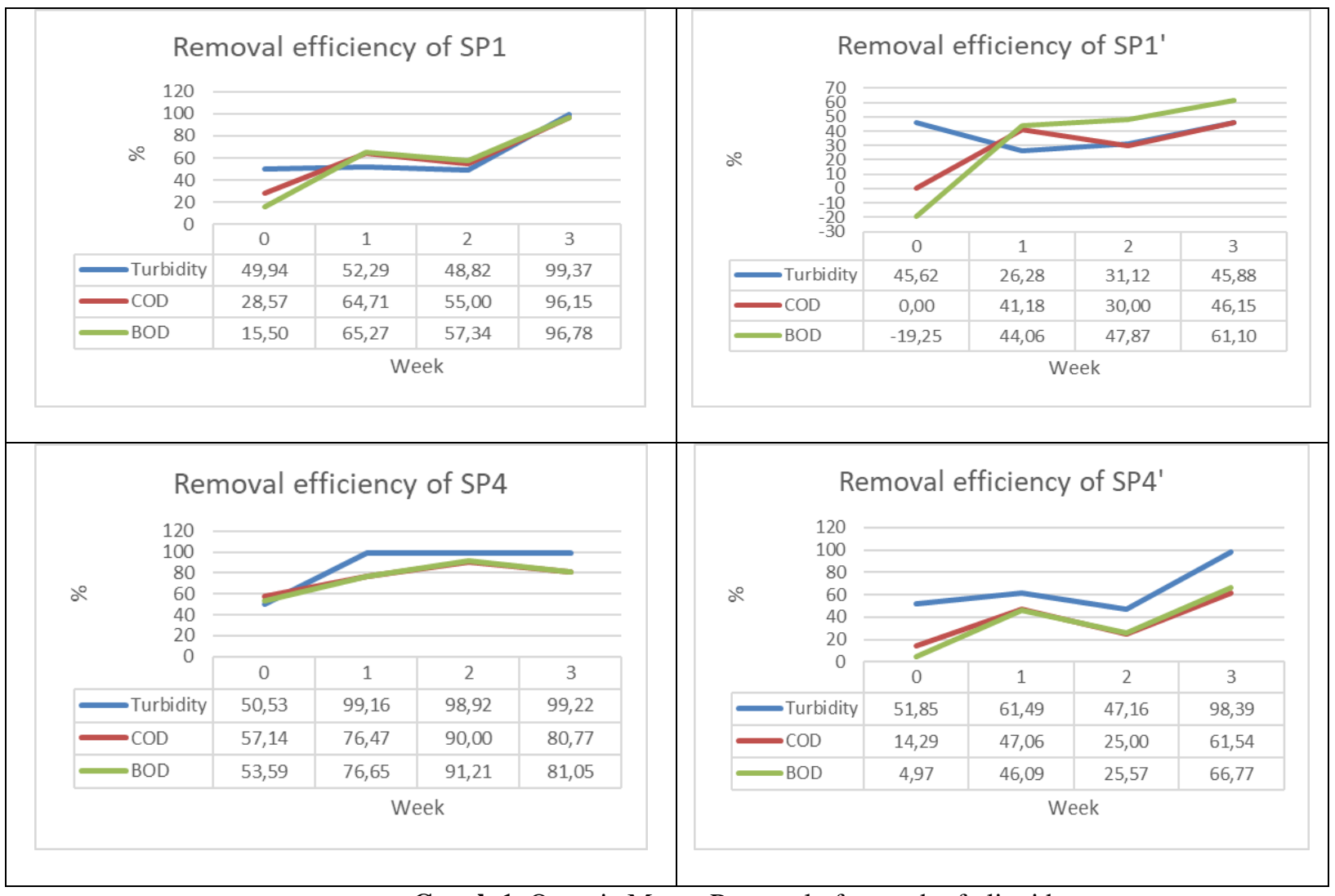

Graph 1. Organic Matter Removal of treated tofu liquid waste

Graphs of efficiency removal seems overlap between $\mathrm{CODcr}_{\text {and }} \mathrm{BOD}_{5}$ and showed that there was a consistency of organic matter removal versus time. CODcr and $\mathrm{BOD}_{5}$ at $\mathrm{SP} 1$ was $96 \%$ and $97 \%$ respectively and at SP4 was around $81 \%$ at third week of study whereas at $\mathrm{SP} 1$ ' for CODcr and $\mathrm{BOD}_{5} 46 \%$ and $61 \%$ respectively. CODcr and $\mathrm{BOD}_{5}$ at $\mathrm{SP} 4$ ' were $61 \%$ and $64 \%$ more less the same with those in SP1'. Fluctuation of efficiency removal every week might be caused also by the age of casts and the bacteria formed resting stages for first and second week of study in reactor A. In the end of second week and beginning of third week there were young earthworms participated for digesting organic matter resulting the efficiency removal was high. High percentage of organic matter removal (turbidity, $\mathrm{BOD}_{5}$ and $\mathrm{CODcr}$ ) mainly mediated by microorganisms in the intestine of earthworms. The process of intake organic matter through its body wall(Sinha, Bharambe, and Chaudhari 2008) and break down through intestine which contains a large number of enzymes in its digest tract(Aira, Monroy, and Domínguez 2007; Prabha et al. 2007). Study has demonstrated that abundance and enzymatic activities of earthworm had significant correlation with treatment efficiency in reactor(Meiyan, Xiaowei, and Jian 2010). It is certainly proven that the growth of earthworm dependent on kind of food, environment condition and also type of species as has mentioned that $L$. rubellus has high protein and fat in its body rather than L. terestris and P. excavates and potential to be used as protein source for feeding animal (Damayanti, Sofyan, and Julendra 2008). It also indicated that $L$ rubbelus might be absorbed and digested organic matter bigger that another species since has proven that its casts bigger than another species as described before. 


\section{Conclusion}

Study has indicated that $L$ rubellus grows faster when feeding with tofu liquid in $\mathrm{pH}$ range $4-5$. Body weight and population of $L$ rubellus increased in room temperature. L rubellus can regulate $\mathrm{pH}$ become neutral in reactor to support the growth of organic matter eaterorganisms. L rubellus also magnification microorganism in its intestine for removing high concentration of organic matter and then releases casts contains microorganism for removing organic matter in reactor. High removal efficiency of organic matter in tofu liquid waste ensure whole tofu production process become valuable especially for its liquid waste. Tofu liquid waste can be introduced as alternative food for feeding L rubellus in vermiculture. Several of supports material in reactor become our concern for future study, relates to growth of organic matter eater-organisms.

\section{Acknowledgments}

We are grateful for the research unit for clean technology, LIPI and Environmental Engineering Department, Faculty of Civil Engineering and Planning, Institute Technology Nasional Bandung which has been providing the laboratories facilities for doing research and also for technicians in laboratories who has assisted us for preparing chemicals for analysis.

\section{Reference}

Aira, Manuel, Fernando Monroy, and Jorge Domínguez. 2007. "Earthworms Strongly Modify Microbial Biomass and Activity Triggering Enzymatic Activities during Vermicomposting Independently of the Application Rates of Pig Slurry." Science of the Total Environment 385 (1-3): 252-61. https://doi.org/10.1016/j.scitotenv.2007.06.031.

Aira, Manuel, Jessica Olcina, Marcos Pérez-Losada, and Jorge Domínguez. 2016. “Characterization of the Bacterial Communities of Casts from Eisenia Andrei Fed with Different Substrates.” Applied Soil Ecology 98: 103-11. https://doi.org/10.1016/j.apsoil.2015.10.002.

Aira, Manuel, Marcos Pérez-Losada, and Jorge Domínguez. 2018. "Diversity, Structure and Sources of Bacterial Communities in Earthworm Cocoons.” Scientific Reports 8 (1): 1-9. https://doi.org/10.1038/s41598-018-25081-9.

Alamu, Emmanuel Oladeji, Gondwe Therese, Phumzile Mdziniso, and Maziya-Dixon Bussie. 2017. “Assessment of Nutritional Characteristics of Products Developed Using Soybean (Glycine Max (L.) Merr.) Pipeline and Improved Varieties." Cogent Food \& Agriculture 3 (1). https://doi.org/10.1080/23311932.2017.1398042.

Alauzet, Nathalie, Sevastianos Roussos, Henri Carreau, and Michel Vert. 2001. "Microflora Dynamics in Earthworms Casts in an Artificial Soil (Biosynthesol) Containing Lactic Acid Oligomers.” Brazilian Archives of Biology and Technology 44 (2): 11319. https://doi.org/10.1590/S1516-89132001000200001.

Byambas, Patrick, Jean Luc Hornick, Didier Marlier, and Frederic Francis. 2019. "Vermiculture in Animal Farming: A Review on the Biological and Nonbiological Risks Related to Earthworms in Animal Feed.” Cogent Environmental Science 5 (1): 1-12.

www.sciri.org

(C) 2021, Scientific Research Journal

http://dx.doi.org/10.31364/SCIRJ/v9.i10.2021.P1021983

This publication is licensed under Creative Commons Attribution CC BY. 
https://doi.org/10.1080/23311843.2019.1591328.

Byzov, Boris A., Nikita V. Khomyakov, Sergei A. Kharin, and Alexander V. Kurakov. 2007. "Fate of Soil Bacteria and Fungi in the Gut of Earthworms.” European Journal of Soil Biology 43 (SUPPL. 1). https://doi.org/10.1016/j.ejsobi.2007.08.012.

Canti, Matthew G., and Trevor G. Piearce. 2003. "Morphology and Dynamics of Calcium Carbonate Granules Produced by Different Earthworm Species.” Pedobiologia 47 (5-6): 511-21. https://doi.org/10.1078/0031-4056-00221.

Cooper, Edwin, Kyle Hirabayashi, and Mariappan Balamurugan. 2012. "Dilong: Food for Thought and Medicine.” Journal of Traditional and Complementary Medicine 2 (4): 242-48. https://doi.org/10.1016/S2225-4110(16)30110-9.

Crang, Richard E., Robert C. Holsen, and John B. Hitt. 1968. "Calcite Production in Mitochondria of Earthworm Calciferous Glands." BioScience 18 (4): 299-301. https://doi.org/10.2307/1294220.

Damayanti, E M A, Ahmad Sofyan, and Hardi Julendra. 2008. "Daya Antimikroba Tepung Cacing Tanah Lumbricus Rubellus Dan Potensinya Sebagai Aditif Dalam Pakan Ternak Daya Antimikroba Tepung Cacing Tanah Lumbricus Rubellus Dan” 25 (January): 123-28.

Didur, Oleh, Yurii Kulbachko, Yuliia Ovchynnykova, Alevtyna Pokhylenko, and Tatyana Lykholat. 2019. “Zoogenic Mechanisms of Ecological Rehabilitation of Urban Soils of the Park Zone of Megapolis: Earthworms and Soil Buffer Capacity.” Environmental Research, Engineering and Management 75 (1): 24-33. https://doi.org/10.5755/j01.erem.75.1.21121.

Edwards, Clive A., and K. E. Fletcher. 1988. "Interactions between Earthworms and Microorganisms in Organic-Matter Breakdown." Agriculture, Ecosystems and Environment 24 (1-3): 235-47. https://doi.org/10.1016/0167-8809(88)90069-2.

Edy Parwanto, M. L., Mahyunis, Hardy Senjaya, Hosea Jaya Edy, and Syamsurizal. 2016. "Fractionation and Characterization of Proteins in Lumbricus Rubellus Powders.” International Journal of Pharmaceutical and Clinical Research 8 (1): 15-21.

Faisal, M., Farid Mulana, Asri Gani, and Hiroyuki Daimon. 2015. "Physical and Chemical Properties of Wastewater Discharged from Tofu Industries in Banda Aceh City, Indonesia.” Research Journal of Pharmaceutical, Biological and Chemical Sciences 6 (4): $1053-58$.

Fischer, Kathrin, Dittmar Hahn, Wolfgang Hönerlage, and Josef Zeyer. 1997. "Effect of Passage through the Gut of the Earthworm Lumbricus Terrestris L. on Bacillus Megaterium Studied by Whole Cell Hybridization.” Soil Biology and Biochemistry 29 (7): 1149-52. https://doi.org/10.1016/S0038-0717(96)00304-5.

Gago-Duport, L., M. J.I. Briones, J. B. Rodríguez, and B. Covelo. 2008. “Amorphous Calcium Carbonate Biomineralization in the Earthworm's Calciferous Gland: Pathways to the Formation of Crystalline Phases.” Journal of Structural Biology 162 (3): $422-$ 35. https://doi.org/10.1016/j.jsb.2008.02.007.

García-Montero, Luis G., Inmaculada Valverde-Asenjo, María A. Grande-Ortíz, Cristina Menta, and Isabel Hernando. 2013. “Impact www.scirj.org

(C) 2021, Scientific Research Journal

http://dx.doi.org/10.31364/SCIRJ/v9.i10.2021.P1021983

This publication is licensed under Creative Commons Attribution CC BY. 
of Earthworm Casts on Soil PH and Calcium Carbonate in Black Truffle Burns.” Agroforestry Systems 87 (4): 815-26. https://doi.org/10.1007/s10457-013-9598-9.

Ghatnekar, Sudhir D, Bullet F Mahavash Kavian, Bullet M Santosh Sharma, Sumukh S Ghatnekar, Bullet S Gautam Ghatnekar, and Bullet V Angela Ghatnekar. 2010. “Dynamic Soil, Dynamic Plant @2010 Global Science Books Application of Vermi-FilterBased Effluent Treatment Plant (Pilot Scale) for Biomanagement of Liquid Effluents from the Gelatine Industry.”

Gómez-Brandón, María, Manuel Aira, Marta Lores, and Jorge Domínguez. 2011. “Epigeic Earthworms Exert a Bottleneck Effect on Microbial Communities through Gut Associated Processes.” PLOS ONE 6 (9). https://doi.org/10.1371/journal.pone.0024786. Gómez-Brandón, María, Marta Lores, and Jorge Domínguez. 2012. “Species-Specific Effects of Epigeic Earthworms on Microbial Community Structure during First Stages of Decomposition of Organic Matter.” PLoS ONE 7 (2): 1-8. https://doi.org/10.1371/journal.pone.0031895.

Haidir, Muhammad, and Arief Sudrajat. 2014. “Water Footprint Konsumsi Tahu Dan Tempe Di Kota Bandung.” Jurnal Tehnik Lingkungan 20 (1): 20-28. https://doi.org/10.5614/jt1.2014.20.1.3.

Hoang, Duyen T.T., Bahar S. Razavi, Yakov Kuzyakov, and Evgenia Blagodatskaya. 2016. "Earthworm Burrows: Kinetics and Spatial Distribution of Enzymes of C-, N- and P- Cycles.” Soil Biology and Biochemistry 99: 94-103. https://doi.org/10.1016/j.soilbio.2016.04.021.

Hogervorst, E., T. Sadjimim, A. Yesufu, P. Kreager, and T. B. Rahardjo. 2008. "High Tofu Intake Is Associated with Worse Memory in Elderly Indonesian Men and Women.” Dementia and Geriatric Cognitive Disorders 26 (1): 50-57. https://doi.org/10.1159/000141484.

Hortensia, Brito-Vega, and Espinosa-Victoria David. 2009. "Bacterial Diversity in the Digestive Tract of Earthworms (Oligochaeta)." Journal of Biological Sciences.

Jayasena, V., W. Y. Tah, and S. M. Nasar-Abbas. 2014. "Effect of Coagulant Type and Concentration on the Yield and Quality of Soy-Lupin Tofu." Quality Assurance and Safety of Crops and Foods 6 (2): 159-66. https://doi.org/10.3920/QAS2012.0176. Julendra, Hardi, Zuprizal, and Supadmo. 2010. “Penggunaan Tepung Cacing Tanah (Lumbricus Rubellus) Sebagai Aditif Pakan Terhadap Penampilan Produksi Ayam Pedagang, Profil Darah, Dan Kecernaan Protein.” Buletin Peternakan 34 (1): 21-29.

Karsten, G. R., and H. L. Drake. 1995. "Comparative Assessment of the Aerobic and Anaerobic Microfloras of Earthworm Guts and Forest Soils." Applied and Environmental Microbiology 61 (3): 1039-44. https://doi.org/10.1128/aem.61.3.1039-1044.1995.

Knapp, B. A., S. M. Podmirseg, J. Seeber, E. Meyer, and H. Insam. 2009. "Diet-Related Composition of the Gut Microbiota of Lumbricus Rubellus as Revealed by a Molecular Fingerprinting Technique and Cloning." Soil Biology and Biochemistry 41 (11): 2299-2307. https://doi.org/10.1016/j.soilbio.2009.08.011. 
Krulwich, Terry A., George Sachs, and Etana Padan. 2011. "Molecular Aspects of Bacterial PH Sensing and Homeostasis.” Nature Reviews Microbiology 9 (5): 330-43. https://doi.org/10.1038/nrmicro2549.

Kul'bachko, Y. L., O. O. Didur, I. M. Loza, O. E. Pakhomov, and O. V. Bezrodnova. 2015. "Environmental Aspects of the Effect of Earthworm (Lumbricidae, Oligochaeta) Tropho-Metabolic Activity on the PH Buffering Capacity of Remediated Soil (Steppe Zone, Ukraine).” Biology Bulletin 42 (10): 899-904. https://doi.org/10.1134/S1062359015100088.

Kumar, Chandrajeet, and Ashok K. Ghosh. 2019. "Fabrication of a Vermifiltration Unit for Wastewater Recycling and Performance of Vermifiltered Water (Vermiaqua) on Onion (Allium Cepa).” International Journal of Recycling of Organic Waste in Agriculture 8 (4): 405-15. https://doi.org/10.1007/s40093-019-0247-9.

Lappin-Scott, Hilary M., and Catherine Bass. 2001. "Biofilm Formation: Attachment, Growth, and Detachment of Microbes from Surfaces.” American Journal of Infection Control 29 (4): 250-51. https://doi.org/10.1067/mic.2001.115674.

Leiva, Javier, Valeria Rodríguez, and Elias Muñoz. 2011. "Influence of Calcium Chloride Concentration on the Physicochemical and Sensory Characteristics of Tofu." Ciencia e Investigación Agraria 38 (3): 435-40. https://doi.org/10.4067/s071816202011000300013.

Li, Y. S., P. Robin, D. Cluzeau, M. Bouché, J. P. Qiu, A. Laplanche, M. Hassouna, P. Morand, C. Dappelo, and J. Callarec. 2008. "Vermifiltration as a Stage in Reuse of Swine Wastewater: Monitoring Methodology on an Experimental Farm.” Ecological Engineering 32 (4): 301-9. https://doi.org/10.1016/j.ecoleng.2007.11.010.

Manyuchi, M M, L Kadzungura, and S Boka. 2013. "Vermifiltration of Sewage Wastewater for Potential Use in Irrigation Purposes Using Eisenia Fetida Earthworms.” World Academy of Science, Engineering and Technology 78 (JUNE 2013 ): 538-42.

Megan Ware, RDN, L.D. 2017. “Everything You Need to Know about Tofu.” September 27, 2017.

https://www.medicalnewstoday.com/articles/278340.

Meiyan, Xing, Li Xiaowei, and Yang Jian. 2010. “Treatment Performance of Small-Scale Vermifilter for Domestic Wastewater and Its Relationship to Earthworm Growth, Reproduction and Enzymatic Activity.” African Journal of Biotechnology 9 (44): $7513-$ 20. https://doi.org/10.5897/ajb10.811.

Mejia, Alfredo, Helen Harwatt, Karen Jaceldo-Siegl, Kitti Sranacharoenpong, Samuel Soret, and Joan Sabaté. 2018. “Greenhouse Gas Emissions Generated by Tofu Production: A Case Study.” Journal of Hunger and Environmental Nutrition 13 (1): $131-42$. https://doi.org/10.1080/19320248.2017.1315323.

Mihara, H., H. Sumi, T. Yoneta, H. Mizumoto, R. Ikeda, M. Seiki, and M. Maruyama. 1991. “A Novel Fibrinolytic Enzyme Extracted from the Earthworm, Lumbricus Rubellus.” Japanese Journal of Physiology. https://doi.org/10.2170/jjphysiol.41.461.

Ndiaye, Awa, Harinaivo A. Andrianisa, Sidesse S.Y. Saapi, Odilon A. Changotade, Amare T. Adugna, Yacouba Konate, and Amadou www.scirj.org

(C) 2021, Scientific Research Journal

http://dx.doi.org/10.31364/SCIRJ/v9.i10.2021.P1021983

This publication is licensed under Creative Commons Attribution CC BY. 
H. Maiga. 2019. “Assessment on Overall Efficiency of Urban Greywater Treatment by Vermifiltration in Hot Climate:

Enhanced Pollutants Removal.” Environmental Technology (United Kingdom) 0 (0): 1-19.

https://doi.org/10.1080/09593330.2018.1561755.

Nie, E., D. Wang, M. Yang, X. Luo, C. Fang, X. Yang, D. Su, L. Zhou, and Z. Zheng. 2015. "Tower Bio-Vermifilter System for Rural Wastewater Treatment: Bench-Scale, Pilot-Scale, and Engineering Applications.” International Journal of Environmental Science and Technology 12 (3): 1053-64. https://doi.org/10.1007/s13762-013-0479-6.

Oktariany, Aditha, and Sutrasno Kartohardjono. 2018. "Effect of Coagulant Dosage on Tofu Industry Wastewater Treatment in Combination with Ultrafiltration Process Using Polysulfone Membrane.” E3S Web of Conferences 67. https://doi.org/10.1051/e3sconf/20186704004.

Parle, J. N. 1963a. “A Microbiological Study of Earthworm Casts.” Journal of General Microbiology 31 (1): 13-22. https://doi.org/10.1099/00221287-31-1-13. - 1963b. "Micro-Organisms in the Intestines of Earthworms." Journal of General Microbiology 31 (1): 1-11. https://doi.org/10.1099/00221287-31-1-1.

Persulessy A E, Rosmalina RT, Hartati E, Putra RD. 2020. “Tofu's Liquid Waste Treatment by Continuous Vermibiofilter ColumnType Reactor.” In . Vol. 483. https://iopscience.iop.org/issue/1755-1315/483/1: https://iopscience.iop.org/journal/1755-1315. https://doi.org/10.1088/1755-1315/483/1/012014.

Prabha, M. Lakshmi, Indira A. Jayaraaj, R. Jeyaraaj, and Srinivasa Rao. 2007. "Comparative Studies on the Digestive Enzymes in the Gut of Earthworms, Eudrilus Eugeniae and Eisenia Fetida.” Indian Journal of Biotechnology 6 (4): 567-69.

Prabhakaran, Molamma P., Conrad O. Perera, and Suresh Valiyaveettil. 2006. "Effect of Different Coagulants on the Isoflavone Levels and Physical Properties of Prepared Firm Tofu." Food Chemistry 99 (3): 492-99. https://doi.org/10.1016/j.foodchem.2005.08.011.

Rahmat, Budy, Tedi Hartoyo, and Yaya Sunarya. 2014. "Biogas Production from Tofu Liquid Waste on Treated Agricultural Wastes.” American Journal of Agricultural and Biological Science 9 (2): 226-31. https://doi.org/10.3844/ajabssp.2014.226.231. Räty, Mika, and Veikko Huhta. 2003. "Earthworms and PH Affect Communities of Nematodes and Enchytraeids in Forest Soil." Biology and Fertility of Soils 38 (1): 52-58. https://doi.org/10.1007/s00374-003-0614-5.

Reynolds, John Warren, John W Reynolds Wilma, and M Reynolds. 2017. “In,” no. April.

Salmon, Sandrine. 2001. "Earthworm Excreta (Mucus and Urine) Affect the Distribution of Springtails in Forest Soils." Biology and Fertility of Soils 34 (5): 304-10. https://doi.org/10.1007/s003740100407.

Schönholzer, Frank, Dittmar Hahn, and Josef Zeyer. 1999. “Origins and Fate of Fungi and Bacteria in the Gut of Lumbricus Terrestris www.sciri.org

(C) 2021, Scientific Research Journal http://dx.doi.org/10.31364/SCIRJ/v9.i10.2021.P1021983

This publication is licensed under Creative Commons Attribution CC BY. 
L. Studied by Image Analysis.” FEMS Microbiology Ecology 28 (3): 235-48. https://doi.org/10.1016/S0168-6496(98)00111-1. Septianda, Imannita, Kartuti Debora, and Maftuchah Rochmanti. 2012. "Effect of Earthworms (Lumbricus Sp.) Extract Antibacterial Activity Against The Bacteria (Salmonella Typhii).” Folia Medica Indonesiana 48 (3): 102-3.

https://biomedpharmajournal.org/vol10no4/extract-of-earthworms-lumbricus-rubellus...\%0A.

Shen, Yu. 2010. "Earthworms in Traditional Chinese Medicine: (Oligochaeta: Lumbricidae, Megascolecidae).” Zoology in the Middle East 51 (December): 171-73. https://doi.org/10.1080/09397140.2010.10638470.

Shih, M. C., H. J. Hou, and K. C. Chang. 1997. "Process Optimization for Soft Tofu.” Journal of Food Science 62 (4): 833-37. https://doi.org/10.1111/j.1365-2621.1997.tb15466.x.

Singh, Rajneesh, Puspendu Bhunia, and Rajesh R. Dash. 2019. “Optimization of Organics Removal and Understanding the Impact of HRT on Vermifiltration of Brewery Wastewater." Science of the Total Environment 651: 1283-93.

https://doi.org/10.1016/j.scitotenv.2018.09.307.

Singleton, David R., Paul F. Hendrix, David C. Coleman, and William B. Whitman. 2003. "Identification of Uncultured Bacteria Tightly Associated with the Intestine of the Earthworm Lumbricus Rubellus (Lumbricidae; Oligochaeta).” Soil Biology and Biochemistry 35 (12): 1547-55. https://doi.org/10.1016/S0038-0717(03)00244-X.

Sinha, Rajiv K., and Gokul Bharambe. 2006. "Removal of BOD, COD from Dairywaste.Pdf."

Sinha, Rajiv K., Gokul Bharambe, and Uday Chaudhari. 2008. "Sewage Treatment by Vermifiltration with Synchronous Treatment of Sludge by Earthworms: A Low-Cost Sustainable Technology over Conventional Systems with Potential for Decentralization." Environmentalist 28 (4): 409-20. https://doi.org/10.1007/s10669-008-9162-8.

Sinha, Rajiv K., Krunal Chauhan, Dalsukh Valani, Vinod Chandran, Brijal Kiran Soni, and Vishal Patel. 2010. "Earthworms: Charles Darwin's 'Unheralded Soldiers of Mankind': Protective \&amp; Productive for Man \&amp; Environment.” Journal of Environmental Protection 01 (03): 251-60. https://doi.org/10.4236/jep.2010.13030.

Sukalingam K, Ganesan K, Das S, Thent ZC. 2015. “An Insight into the Harmful Effects of Soy Protein: A Review.” La Clinica Terapeutica 166 (3): 131-39. https://europepmc.org/article/med/26152621.

Versteegh, Emma A.A., Stuart Black, and Mark E. Hodson. 2014. "Environmental Controls on the Production of Calcium Carbonate by Earthworms." Soil Biology and Biochemistry 70: 159-61. https://doi.org/10.1016/j.soilbio.2013.12.013.

Vidal, Alix, Francoise Watteau, Laurent Remusat, Carsten W. Mueller, Thanh Thuy Nguyen Tu, Franz Buegger, Sylvie Derenne, and Katell Quenea. 2019. "Earthworm Cast Formation and Development: A Shift from Plant Litter to Mineral Associated Organic Matter.” Frontiers in Environmental Science 7 (APR): 1-15. https://doi.org/10.3389/fenvs.2019.00055.

Xu, Xin, Shifu Xiao, Tri Budi Rahardjo, and Eef Hogervorst. 2015. “Tofu Intake Is Associated with Poor Cognitive Performance

www.scirj.org

(C) 2021, Scientific Research Journal

http://dx.doi.org/10.31364/SCIRJ/v9.i10.2021.P1021983

This publication is licensed under Creative Commons Attribution CC BY. 
among Community-Dwelling Elderly in China." Journal of Alzheimer's Disease 43 (2): 669-75. https://doi.org/10.3233/JAD141593.

Zhang, Qing, Chenzhi Wang, Bokang Li, Lin Li, Derong Lin, Hong Chen, Yaowen Liu, et al. 2018. "Research Progress in Tofu Processing: From Raw Materials to Processing Conditions." Critical Reviews in Food Science and Nutrition 58 (9): $1448-67$. https://doi.org/10.1080/10408398.2016.1263823. 